\title{
THE EXPANSION OF COAL MINING IN THE DEPRESSION AREAS - A WAY TO DEVELOPMENT?
}

\author{
Stanislav Martinát ${ }^{\mathrm{a} *}$, Josef Navrátil ${ }^{\mathrm{b}}$, Petr Dvořák ${ }^{\mathrm{a}}$, Petr Klusáček ${ }^{\mathrm{a}}$, \\ Marian Kullac ${ }^{c}$ Josef Kunc ${ }^{\mathrm{d}}$, Marek Havlíček \\ ${ }^{a}$ Department of Environmental Geography, Institute of Geonics, Academy of Sciences of the Czech Republic, Czech Republic \\ ${ }^{b}$ Department of Biological Studies, Faculty of Agriculture, University of South Bohemia in České Budějovice, Czech Republic \\ c Department of Geography, Faculty of Science, Pavol Jozef Šafárik University in Košice Jesenná 5, Košice, Slovakia \\ ${ }^{d}$ Department of Regional Economics and Administration, Faculty of Economics and Administration, \\ Masaryk University, Brno, Czech Republic \\ e Silva Tarouca Research Institute for Landscape and Ornamental Gardening, Brno, Czech Republic
}

\begin{abstract}
The coal has been mined in the Karviná area for more than 150 years. During the course of time mining areas were continuously extended at the expense of the settled areas. At the beginnings the mining was limited, but later, namely under conditions of centrally planned economy in the period between 1950s and 1980s, it was heavily intensified. Then, as a result of economic restructuring of the Czech Republic mining was reduced in the region to be re-developed in the last decade again. The expansion of coal mining has been continuously affecting the socio-economic structure of local population (huge working immigration, industrialisation, construction of mass housing for miners - miners dormitories, later housing estates etc., displacement of settlements), surrounding landscape (subsidence of terrain, undermining, hydrological changes and formation of artificial lakes, occurrence of plenty of post-mining brownfields after the reduction of mining etc.), but also contemporary outward, image and socio-spatial structure of cities (dominance housing in housing estates, effects of communists spatial urban planning etc.). Currently, negotiations about expansion of coal mining are in progress in this region, namely the city parts of Karviná (Staré Město) and Orlová (Výhoda) should be affected. In the introductory parts of this paper social, economical and environmental aspects of coal mining on the development of regions and connected problems are discussed and both cities are shortly presented. The questionnaire survey focused on perceptions of after-mining renewal and potential expansion of mining in the area of cities of Karviná and Orlová was conducted $(n=1000)$. As the most important predictor that influences perception of mining and renewal, employment in mining companies has been identified. The higher education respondents achieved, the higher level of opposition against mining was manifested. The correlation was also found between the level of income and the agreement with expansion of mining. It can be concluded that employees of mining company, less educated population and people with higher income agreed with economic development of the city that is based on mining.
\end{abstract}

Key words: Coal mining, Perception of mining, Karviná, Orlová, Czech Republic.

Article Info: Manuscript Received: April 3, 2014; Revised: May 24, 2014; Accepted: May 25, 2014; Online: May 31, 2014.

\section{Introduction}

The paper is trying to explore the perception of expansion of mining by population of affected areas whose quality of life is without doubt heavily influenced by mining from economic, social and environ-

* Corresponding author:

Address: Department of Environmental Geography,

Institute of Geonics, Academy of Sciences of the Czech Republic,

Studentská 1768, 70800 Ostrava, Czech Republic.

Telephone: + 420598969327

Email:martinat@geonika.cz mental points of view. In the theoretical part of the paper attention is devoted to spatial contexts and coherences of urban spaces and problems of postmining areas. In the next part model research area is presented, which is followed by evaluation of questionnaire survey results that was carried out among the local population. In the final parts of the paper knowledge experience during the presented research is summed-up and recommendations and possible actions are being discussed. 
The aim of the paper is to analyse importance and mutual interdependences of factors that affect level of agreement of local population with renewal and expansion of mining. The problem is followed in the case study area of cities of Karviná and Orlová in the eastern part of the Czech Republic, where expansion of mining is being recently discussed.

\section{Theoretical overview of the problem}

The areas in the East-Central Europe, where coal mining has been operated in the last decades or coal is still mined in limited way, has been recently experiencing wide set of problems. Such problems are not only solely connected to economic issues like oneway focus of local economy and its vulnerability in context of dynamics of recent global economic trends (Fieldhouse and Hollywood, 1999 or Perry, 2003), but also to social problems like unemployment of specific groups of population, low educational structure and socio-pathological phenomena have to be taken into account.

Another type of problems is linked to specifics of demography of mining and post-mining areas (i.e. huge immigration during the times of boom of mining, huge emigration and dynamic aging of population in after mining period - Vaishar, 2002, 2006) or to problems connected with search of new identity of local population (Strangleman, 2002, Sucháček and Malinovský 2012).

The environmental problems connected to expression of mining activities in landscape (decreases of terrain, changes of hydrology of such areas, possible contaminations - i.e. Harfst and Wirth, 2011) or problems linked to anthropogenic expressions of mining activities (occurrence heaps and artificial lakes, changes of biological diversity - i.e. Schulz and Wiegleb, 200o, Sklenička and Charvátová, 2003, Lacina and Koutecký, 2005) has to be mentioned too.

As an integral of problems of mining and postmining areas the occurrence of unused or partly used buildings, sites, technical infrastructure of former mines could be noted. The occurrence of these brownfieds creates the most visible and the most problematic part of these post-mining areas (e.g. Frantál et al., 2013 or Krzysztofik et al., 2013). The reuse of such brownfield sites is rather challenging issue, since complexity of connected problems generate plenty of obstacles. The solution of above mentioned problems is not simple and quick. Many approaches and tools of regional policies are applied to help such areas, nevertheless their success or at least usefulness is strongly influenced by attitudes of local population towards such plans and their implementation (Alexandrescu et al., 2014).

\section{The consequences of brownfields and regional development}

The occurrence of brownfields might be listed among the most important problems that prevent or restrict suitable economic and social development of regions,. In the Czech Republic the brownfields are defined in the National Strategy for Regeneration of Brownfields (CzechInvest, 2008) as properties (land, building, sites) that are abandoned, insufficiently used, neglected and might be contaminated. They appear as the relict of former industrial, agricultural, housing, military or other activity. It is not possible to use brownfields suitably and effectively until the regeneration process passes through. As obvious from the above mentioned definition of the term of brownfield, which varies according to different countries and contexts (i.e. Symms, 1994, Bartsch and Collaton, 1997, Alker et al., 200o, Cabernet 2006, Tang and Nathanail, 2012), such sites occur as a consequence of the decline of different types of economic activities including mining. As it is mentioned in the Search study for location of brownfields (CzechInvest, 2007), in the period of 2005-2007 2355 brownfield sites in the areas of the Czech Republic were listed on the area of more than 10300 hectares.

However it has to be stressed that sites with the size of more than 1 hectare were the only ones counted and after-mining brownfields were not covered at all (Vojvodíková et al., 2011). According to expert estimations, both the number and the area of existing brownfields in the Czech Republic are estimated to be four times higher. For geographical locations of mining areas within the Czech Republic, where postmining brownfields occur, see Figure 1. It has to been stressed that among the mentioned mining areas only the Ostrava-Karviná mining area is still partly operated (marked as number 1 in Figure 1), in other mining areas mining was stopped in 1990s. Figure 2 illustrates the development of coal mining in the Czech Republic from early 1980s, when the highest amount of coal was mined (more than 28,2 millions of tons in 1980 ; $88 \%$ of this coal was mined in the OstravaKarviná mining area) to contemporary amount, which is almost by two thirds lower (around 10,2 millions of tons in 2013).

As the main driving forces for occurrence of postmining brownfields socio-political changes in late 1980 s and consequent reduction of mining, deindustrialisation of society and recent global energy transition towards new sources of energy can be mentioned. The de-industrialisation can be defined as the process of social and economic changes of society, which is caused by shift and reduction of industrial (and mining) activities in given area. As stated by Marcussen (1982), within the world wide scale this process is accompanied by the shift of employment in industries from core regions to semi-peripheries and peripheries. 


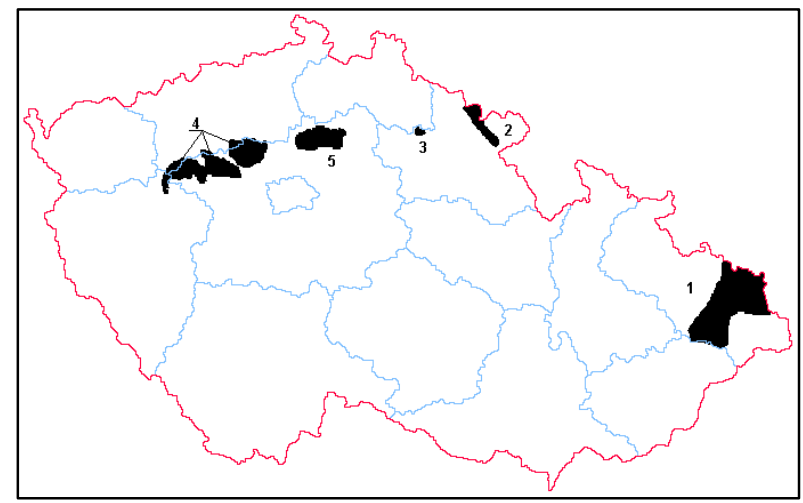

Figure 1. Location of coal mining areas in the Czech Republic

Source: www.geofond.cz/dokumenty/nersur_rocenky/ rocenkanerudyoz/html/c-uhli.htm

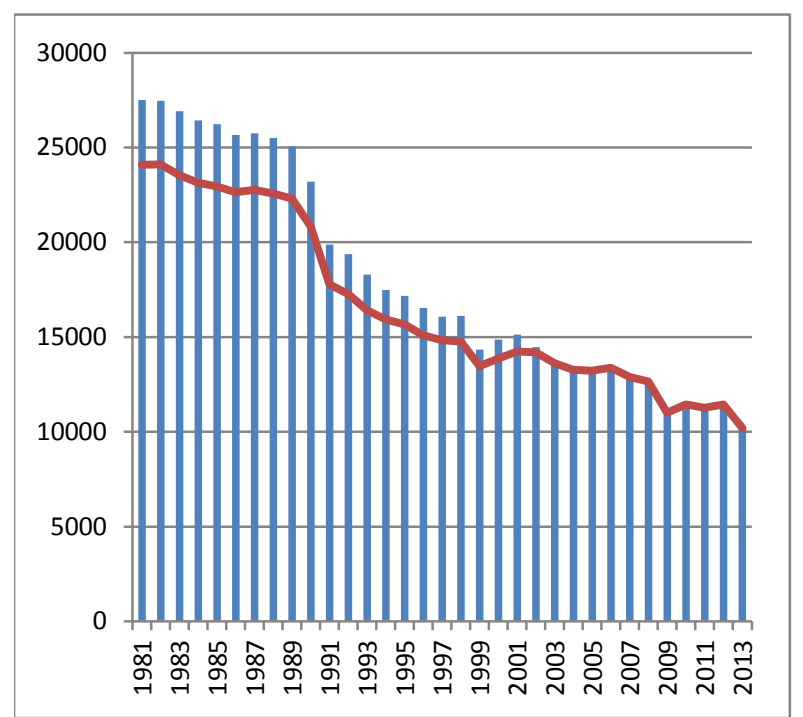

Figure 2. Development of coal mining in the Czech Republic and in the Ostrava-Karviná mining area (1981-2013, in millions of tons)

Source: Czech Statistical Office, Historical yearbook of statistics on energetics (2013)

ww.czso.cz/csu/2012edicniplan.nsf/p/8113-12.

This process, which is accompanied by the increase of employment in services in case of the developed economies, has been evident since 1960s and it causes the change in spatial pattern of distribution of industrial activities in favour of its location on greenfields and thus occurrence of brownfields. The mentioned trend produces strong impulses, but also risks for society that has to face consequent problems and challenges concerning structural unemployment, demographic specifics or undisputed shift in perceptions of health (Keller, 2012) and environmental risks (Kunc et al., 2014a) connected to reduction of industrial activities and its relicts.

This general de-industrialization trend has been in case of coal mining activities modified by both logical commitment to locations with coal deposits and recently declining price and demand for coal on global markets. In spite of this fact, the tendencies to expand coal mining to areas with better natural conditions (and more profitable mining economy) are still important. One of limitation factors for the expansion of mining to settled areas is the controversial societal carrying capacity of this process. With ongoing de-industrialisation of society the perception of places by population has been dramatically changed both by local population or tourists. The activities, which awakened enthusiasm of public by its technical perfection decades ago (constructions of dams, mines, factories, nuclear power plants etc.) are recently considered from the completely different points of view. The disruption of landscape character, building-up of agricultural land, effects of mining activities, expansion of mining beyond given mining limits - these are phenomena that have been recently rising wide public debates on positive contributions and negative impacts of individual economic activities. Thus it is essential to study and pay attention to the perception of mining and its expansion.

The problems of heavy industrialised areas have specific expression in cities of the East-Central Europe, which were dynamically developed during the times of application of the centrally-planned economy in this area during 1950s-1980s (Kunc et al., 2014 b or Tvrdoň et al., 2012). These so called post-socialistic industrial cities were typical for their one-sided economic activities of local population in mining or heavy industries, for their very low employment in services, typically significant daily commuting, typical transport infrastructure concerning direction and capacity. The occurrence of such cities was experienced in all countries of former eastern bloc - e.i. Havírov, Orlová, Karviná, Most, Litvínov in the Czech Republic; Nová Dubnica in Slovakia; Nowa Huta in Poland; Magnitogorsk in Russia; Eisenhüttenstadt in the eastern part of Germany; Tatabánya in Hungary; Hunedoara in Romania etc. As one of the typical identification signs of such cities very high share of local population that houses in housing estates made of panels can be determined as a result of mass working immigration supported by central governments during the socialistic era.

The mentioned problems are particularly evident in case of cities with the economy based on mining that experienced a strong decay of mining after sociopolitical changes in early 1990s. The economies of transition countries in the East-Central Europe were facing this challenge in the early 1990s, when questions of future of mining emerged. As pointed out by Dvořáček (1998), in principle two possibilities came along. Either to reduce mining dramatically, or to choose a way of gradual steps in reduction of mining that would not be accompanied by such high societal risks. If we take mining in the Ostrava-Karviná mining area as an example, while in the western part of this area (Ostrava) the first mentioned way was ap- 
plied and all mined were closed until 1994, in the eastern part of the area (Karviná area) the latter way was applied. It means that mining was reduced here and restructured in 1990s, but until nowadays it has been still in operation. Since in all other coal mining areas the mining has been quickly terminated until the late 1990s, the Karviná areas is now the only coal mining area in the Czech Republic.

As emphasized by Smolová et al. (2007), in the context of recent global energy crisis and an increase in energy prices in future these steps could be perceived as controversial. Other authors propose a solution more coherent with the process of contemporary energy transition towards the use of renewable energies and energy efficiency. They propose the re-use of such brownfields for location of facilities that generate renewable energy (Bungart, et al., 200o, Adelaja et al., 2010, Klusáček et al., 2011). Such re-use of brownfields provides suitable space for regulation and support mechanisms in the form of financial incentive from national or European level towards sustainable use of land. Nevertheless, as pointed out by e.g. Frantál (2008) or Frantál and Kučera (2009, 2010), the location of facilities for generation of renewable energy in the landscape are related to frequent controversies and socio-spatial conflicts. However, as proved in studies of Frantál and Kunc (2011), in areas affected by mining the level of acceptance of renewable energies is usually higher than in other areas.

The tourism is another re-use option of brownfields that has to be necessarily commented on in brief. The brownfields as areas that are partly (or totally) abandoned and neglected cause the decrease of economic potential of sites located in their neighbourhoods, prices of such real estate are lowered and they generate bad stigma or image for such sites and areas. The tourism in the form of interpretative trails, field trips and excursions could improve the reputation of these areas and attract segments of tourists who seek for such sites.

The environmental aspects of post-mining landscape are widely surveyed. The environmental consequences of massive decays of mining in the eastern parts of Germany are studied by means of aerial pictures analyses by e.g. Schmidt and Glaesser (1998), revitalisation options of post-mining areas are surveyed on the example of Poland by e.g. Strzyszcz (1996) or Helios Rybicka (1996).

\section{Perception of mining and its main factors}

Nevertheless the decay of mining is connected to huge social problems as well. As the most problematic the unemployment has to be mentioned, which is caused by difficult adaptation of former miners for employment in other sectors or their health prob- lems. In further combination with the usually low educational structure of local population rising of complex structural problems is enabled, which are increasingly difficult to be solved during the course of time.

Other specifics of mining areas are based on its demography. In spite of huge immigration waves of young workers between 1950 os and 1980s, who usually started their families very quickly, nowadays such mining areas are relatively old from the point of view of average age and demographic structure. The lack of local jobs (and thus newcomers) causes unattractiveness also for young local educated population, who tends to migrate to the more attractive areas. The result of this trend is that mining (and post-mining) areas suffer from the process of ageing, where population in productive age is continuously declining (Krejčí et al., 2011 or Káčerová et al., 2013).

The attitudes of population of mining cities towards mining and connected problems are usually strongly polarized. The variety of these attitudes starts with total resignation, through support of mining expansion among miners, to anti-mining activism of part of population and non-profit organisations. The discussions about possible expansion of mining are influenced by interests of investors, local population, employees of mining and related companies or non-profit organisations that do not usually support mining. The renewal of mining (if possible) or its expansion belongs to important development approaches, which aim to improve economic and social status of the areas.

Nevertheless, such mining expansion brings about huge amount of further economic, social and environmental risks. Regarding the fact that potential expansion of mining concern interests of all inhabitants of the area and not just selected population groups, deepening of knowledge about structure and interdependences of factors, which influence opinions of local population, seems to be crucial.

The perception of renewal or expansion of mining was studied by e.g. Lockie et al. (2009), who based on their researches done in Austrialia warn that the labour recruitment, social infrastructure policies and investment strategies are decisive in reducing the opposition towards mining projects. Moffat and Pless-Mulloli (2003), who surveyed the perception of health risks in the proximity of mining areas in the United Kingdom, point out the differences between intensities of measured pollutants and their perception and they stress the necessity to focus on the exploration of attitudes of non-activist population. As it was discussed by Suopajärvi (2013) in the study focused on Finland, social aspects of further development of mining should be surveyed in detail with the respect to transparency and usability of such results for both commercial and decisive sphere as well. 


\section{The case study area}

For exploring the factors that affect the level of agreement of renewal or expansion of coal mining, the case study area of two neighbouring cities was delimited (the city of Karviná, the city of Orlová in the Moravian-Silesian Region in the eastern part of the Czech Republic - see Figure 3). Both mentioned cities were connected to coal mining in the OstravaKarviná mining area for more than 150 years. Both cities were originally founded in the 13th century and their development until late $18^{\text {th }}$ century didn't experience radical changes. The cities lived their ordinary lives of a small town with small crafts and tradesmen and were surrounded by agricultural hinterland in the landscape typical for their large number of ponds. The dramatic economic development started with the beginnings of industrialisation and finding of coal in the first part of the 19th century. Initially the extensive way of mining in the area was intensified and wide distribution of mined coal was facilitated by connecting the mining areas to big cities and regions of the Habsburg monarchy via railway lines (1870).

The coal mining and heavy industries were continuously becoming the driving development forces of the economy of both cities and the whole region too. Such economic development was accompanied by huge immigration of population since mid-19th century, which completely changed the social structure of the studied area. The urban development of both growing cities started to be deformed and adapted to mining and industries and new cores of development arose in the proximity of mines and factories (in the form of dormitories for miners etc.).

While until the end of the WWII the effects of mining in the landscape were not so dramatic, after communist putsch in Czechoslovakia (1948) mining was hugely intensified and the effects on the landscape dramatically increased. The coal mining and heavy industries as the main paradigms of communist economic policy were unprecedently developed in the region by means of the central-planned economy. Since both cities were located on rich deposits of coal, during 1960s demolition and displacement of both cities started to be discussed. While in case of the city of Orlová the plan was not implemented and just one part of the historical settlement was demolished, in the latter case the whole city of Karviná was destroyed and its population was shifted further to the east to the area of the city of Fryštát. The paradox is that the original name of the displaced city (Karviná) was kept and nowadays Fryštát i sone of the city quarters of Karviná. With a certain extent of exaggeration, the city lost its territory, but not its name.

The historical cores of both cities fell prey to the mining and their core settlements was shifted to the typical mass housing estates of socialistic style, which now accounts for a dominant way of housing in the area. Thus, by the end of 1980 os pre-transition starting points of both cities can be illustrated by very similar features such as mass employment in heavy industries and mines (more than $50 \%$ of economically active population in 1991), high level of daily working commuting out of the cities (in case of Orlová almost $60 \%$ of economically active population), very high level of housing in mass housing estates (in case of Karviná $92 \%$ of population), very low educational structure of local population ( $4 \%$ of population with university education in 1991 on average) or strong polluted environment etc.

During the course of the transition period both cities were experiencing strong socio-economic decline as a consequence of the shift from the centrallyplanned economy towards the market economy. The reduction of heavy industries and coal mining in the areas and a lack of alternative jobs led to a dramatic increase of unemployment in both cities of Karviná and Orlová. By the end of the 2oth century the unemployment rate reached almost $20 \%$, by the end of the following decade it oscillated around $15 \%$ with 50 unemployed people per 1 job available (in 2010). The mentioned phenomena, the worsening image of both cities and a bad state of environment caused systematic decreases of population number in both cities. As obvious from data of the last census, during the last two decades (1991-2011) population in Karviná decreased by $16.8 \%$ (56 897 in 2011), in case of Orlová it was $17.7 \%$ (29 896 in 2011). If wider time span is taken into account (1980-2013), population declines are even stronger; in case of Karviná it is more than $27 \%$. Both cities are continuously experiencing processes of shrinkage. This process is connected to cities (or wider areas), where huge population decreases and economic declines are taking place, but also where housing, technical and social infrastructure was built for a lot more people. Thus a question arises how such dissonances could be solved with respect to both economic effectiveness and quality of life of the local population (e.g. Bontje, 2004, Haase et al., 2013, Buček and Bleha, 2013).

As shown in Table 1, the share of population employed in industries was continuously decreasing in both cities in the context of de-industrialisation. However, in comparison to the average numbers for the Czech Republic it is still very high in cities of Karviná and Orlová (26.5\% and $29.8 \%$ respectively in 2011). Also daily working commuting flows were dramatically reduced in last two decades. The city of Orlová has to be mentioned in this context, since almost $60 \%$ of local people were daily working commuting out of the city in 1991. Regarding the fact that no big employers are located within this city we can conclude that the increased unemployment was also caused by this phenomenon. 


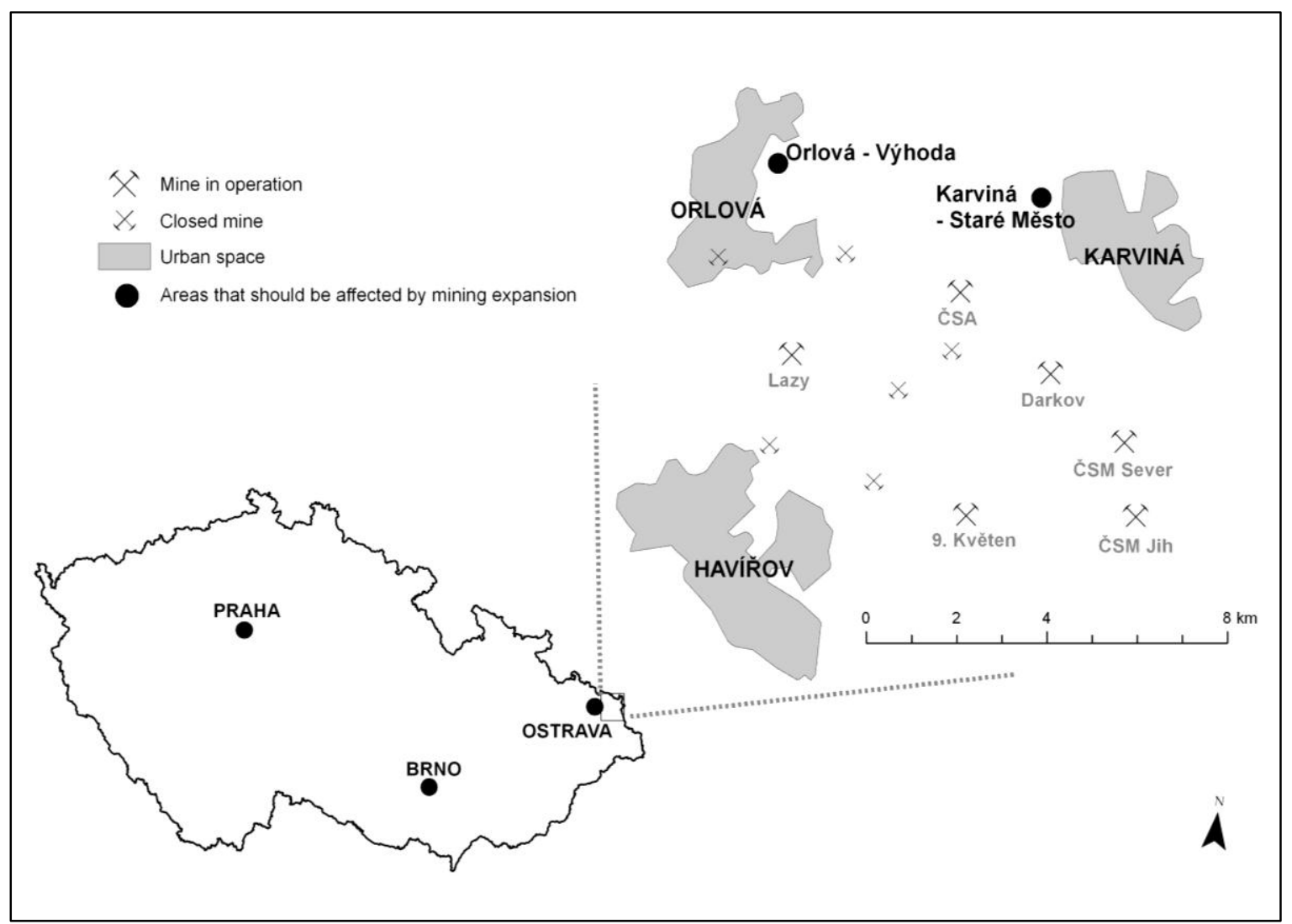

Figure 3. Location of study area within the Czech Republic

Source: own processing

Despite the improvement of educational structure of the studied cities in the last two decades and the presence of public university in city of Karviná, it is still deeply under average in comparison to other comparable cities. The mining company (OKD) is with its more than 15 thousands employees one of the most important employers within the wider region.

In both cities a public debate on possible expansion of coal mining has been recently started. In both cases some parts of the cities will be affected by mining - in Karviná it is Staré Město city quarter, in Orlová a settlement called Výhoda (for the location of both areas see Figure 3). Respondents of the presented survey on perception of expansion of mining the local population of both cities was questioned.

\section{Methods}

The data on perception of mining were collected via written questionnaires completed in both cities. The questionnaire survey was carried out in June 2012. The respondents (older than 18 years) were questioned by trained university students in the streets of both cities. A pilot research survey took place, on a twenty-five-member sample, in March 2012 and, on the basis of its results, the final version of the query tool was prepared (Robinson, 1998). One thousand questionnaires were collected in total and evaluated with a rejection rate close to $20 \%$.

The questionnaire was administered in order to examine the structure of attitudes of population towards partial elements / opinions on expansion of coal mining in the city where they live. Based on literature retrieval (Ray, 1980, Strangleman, 2002, Vargas-Sánches et al., 2009, Lockie et al., 2009 or Krzysztofik et al., 2013, Frantál and Nováková, 2014) such elements are represented by these statements:

1) Coal mining is a perspective branch of economy, which is worth building the image on;

2) To preserve jobs in the coal mining industry is a necessity for the future of the city;

3) The development of other economic activities (e.g. light industries, services) is much more important than the expansion of coal mining;

4) The representatives of the city should support the expansion of coal mining;

5) The pollution in the city is high enough, the expansion of coal mining should not be supporte any more;

6) The surrounding landscape of the city has already been devastated by mining; further expansion of mining can not make it worse;

7) To build places for leisure time activities is a suitable use for areas regenerated after mining; 
Table 1. Employment in industry and daily commuting from Karviná and Orlová (1991, 2001, 2011)

\begin{tabular}{|c|c|c|c|c|c|c|c|c|c|}
\hline & \multicolumn{3}{|c|}{$\begin{array}{l}\text { Share of employment } \\
\text { in industry }\end{array}$} & \multicolumn{3}{|c|}{$\begin{array}{l}\text { Share of daily work commuters } \\
\text { out of city }\end{array}$} & \multicolumn{3}{|c|}{$\begin{array}{l}\text { Share of population with } \\
\text { university education } \\
\text { (in population } 14+\text { ) }\end{array}$} \\
\hline & 1991 & 2001 & 2011 & 1991 & 2001 & 2011 & 1991 & 2001 & 2011 \\
\hline Karviná & $50.3 \%$ & $33.7 \%$ & $26.5 \%$ & $30.5 \%$ & $19.5 \%$ & $17.4 \%$ & $3.7 \%$ & $4.8 \%$ & $7.4 \%$ \\
\hline Orlová & $52.8 \%$ & $37.3 \%$ & $29.8 \%$ & $59.3 \%$ & $40.0 \%$ & $30.1 \%$ & $4.3 \%$ & $4.9 \%$ & $8.0 \%$ \\
\hline
\end{tabular}

Source: Czech Statistical Office, Censuses (1991, 2001, 2011 - www.czso.cz)

8) The most suitable regeneration of after mining areas is to reforest the area;

9) The quality of environment in not important for the future of the city, the most decisive factor is job availability;

10) The city of Karviná (Orlová) is an area in decline.

The level of agreement with the above mentioned statements was measured on the five-point Likertlike scale with " $1=$ I definitely agree" and " $5=$ I definitely disagree" anchoring the scale. The opinion of respondents regarding the expansion of coal mining was also followed by the level of agreement with dependent variable represented by the statement "I agree with the expansion of coal mining to the area of Staré Město (in case of Karviná) and to the area of Výhoda (in case of Orlová)“. To proces the staticstics and to explore interdependences among basic segmentation groups the gender, age, education and the income of the household were also monitored. The information whether the given respondent is a present (or former) employee of the mining company (OKD) was monitored too. The profile of the respondents is shown in Table 2.

The factors of attitudes of population towards partial elements / opinions on the expansion of coal mining in the areas of the city where they live were first identified by the Explorative Factor Analysis (EFA). The principal components analysis method was employed and only the factors with an eigenvalue greater than 1 were assessed, and the results were varimax rotated (Robinson, 1998). Then, for each factor, the composite mean was calculated, i.e. an average value for EFA factor from values of items loaded at least with value of 0.4 on this factor. The values for the level of agreement with statements no. 4 and 6 were first inverted before calculation (they have negative factor loadings).

The influence of individual segmentation kriteria on the individual extracted factors was further evaluated. The predictors of answers on extracted factors were determined using the least squares method of the general linear model in the General Regression Models module of STATISTICA 10 software package.

This module enables the generalization of the linear regression model, so that the effects can be tested for categorical predictor variables as well as for continuous predictor variables and in design with multiple dependent variables (StatSoft 2011).
Table 2. The basic segmentation criteria of respondents

\begin{tabular}{|lc|}
\hline & Gender \\
\hline Female & $51.00 \%$ \\
\hline & $49.00 \%$ \\
\hline $18-25$ & age \\
\hline $26-35$ & $19.94 \%$ \\
\hline $36-45$ & $19.94 \%$ \\
\hline $46-55$ & $19.94 \%$ \\
\hline $56-65$ & $19.94 \%$ \\
\hline above 65 & $19.94 \%$ \\
\hline & $19.94 \%$ \\
\hline Basic & Education \\
\hline Secondary without final graduation & $6.21 \%$ \\
\hline Secondary with final graduation & $30.96 \%$ \\
\hline University & $42.38 \%$ \\
\hline & $20.44 \%$ \\
\hline Not stated & Income \\
\hline $10-15$ thousands CZK & $1.60 \%$ \\
\hline $15-20$ thousands CZK & $34.57 \%$ \\
\hline $20-25$ thousands CZK & $30.76 \%$ \\
\hline $25-30$ thousands CZK & $18.54 \%$ \\
\hline $30-35$ thousands CZK & $9.12 \%$ \\
\hline $35-40$ thousands CZK & $3.71 \%$ \\
\hline above 40 thousands CZK & $1.00 \%$ \\
\hline & $0.70 \%$ \\
\hline No & Mining company \\
\hline Yes & employee \\
\hline & $17.94 \%$ \\
\hline
\end{tabular}

Source: own processing $(\mathrm{n}=1000)$

The multiple linear regression (Nusair and Hua 2010) using the forward selection method to select the independent variables was used to assess the influence of factors of the agreement with the expansion of coal mining on the expression of this agreement. The first run of forward selection was performed and then the data were purged from outliers. Consequently, the process of forward selection was repeated. The model was assessed based on the partial regression graphs and partial residual graphs and the method was assessed by means of the F-test of importance of a regression model (Meloun and Militký 2006). The level of education of respondents was employed in the regression model as relative variable to make linear regression applicable. This was achieved by evaluation of the length of education of respondents in years. 


\section{Results and discussion}

On the basis of the Explorative Factor Analysis (EFA), two factors of attitudes related to expansion of mining in the areas of cities of Karviná and Orlová, explaining $42.9 \%$ of the total variability (Table 3 ), were identified.

The economic aspects are fed by these statements: Statement no. 1: Coal mining is a perspective branch of economy, which is worth building the image on;

Statement no. 2: To preserve jobs in the coal mining industry is a necessity for the future of the city;

Statement no. 3: The development of other economic activities (e.g. light industries, services) is much more important than the expansion of coal mining;

Statement no. 4: The representatives of the city should support the expansion of coal mining;

Statement no. 10: The city of Karviná (Orlová) is an area in decline.

The environmental aspects are fed by these statements:

Statement no. 5: The pollution in the city is high enough, the expansion of coal mining should not be supporte any more ;

Statement no. 6: The surrounding landscape of the city has already been devastated by mining; further expansion of mining can not make it worse;

Statement no. 7: To build places for leisure time activities is a suitable use for areas regenerated after mining;

Statement no. 8: The most suitable regeneration of after mining areas is to reforest the area;

Statement no. 9: The quality of environment in not important for the future of the city, the most decisive factor is job availability.

Table 3. The results of the Explorative Factor Analysis (EFA). Only items with varimax rotated factor loadings greater than 0.4 are shown

\begin{tabular}{|lcc|}
\hline & Factor - 1 & Factor - 2 \\
\hline Statement no. 1 & 0.806 & \\
\hline Statement no. 2 & 0.714 & \\
\hline Statement no. 3 & -0.635 & \\
\hline Statement no. 4 & 0.792 & \\
\hline Statement no. 5 & -0.634 & \\
\hline Statement no. 6 & 0.443 & 0.418 \\
\hline Statement no. 7 & \\
\hline Statement no. 8 & \\
\hline Statement no. 9 & 0.525 \\
\hline Statement no. 10 & 0.500 \\
\hline Eigenvalue & 3.157 & 1.130 \\
\hline$\%$ of total variability & 0.307 & 0.122 \\
\hline
\end{tabular}

Source: own research and processing $(\mathrm{n}=1000)$
The result stating that the economic and environmental factor are important is not surprising and was also noted and proved in number of previous similar researches (Moffat and Pless-Mulloli, 2003, Ivanova, 2007, Lockie et al., 2009). What makes the interpretation of the results quite challenging is the obvious connection of the perception of the decline of cities based on mining with the support for the development of greenery and leisure time areas. It seems that in case of this type of cities greenery and facilities for sports and leisure are lacking, though it could be just an expression of the fact that the majority of population simply doesn't really know how such post-mining areas could be used in future.

The lack of knowledge about good practices concerning possibilities of re-use of these sites is obvious. On the other hand, the support for greenery solution is quite promising from the point of view of the greenhouse gases reduction. The coherences between the decline of the city and the support for the development of greenery and leisure time sites could also be commented in the context of the needs of improvement of the quality of life of local population from the environmental point of view and fair distribution of not only environmental burdens connected to mining activities, but also economic benefits that are generated by mining in sense of the environmental justice theory (Frantál and Nováková, 2014).

With respect to the above mentioned results the influence of the basic segmentation criteria on attitudes towards development of such areas is expected. Regarding the fact that especially age, education and income are not mutually independent variables, it was decided to apply the non-parametric multiple regression with forward selection for assessment of influence of segmentation criteria in both factors. In this way it was possible to determine the group of mutually independent variables which influence decisions on the importance of economic and environmental factor.

The model of predictors of decision on economic factor is significant $(\mathrm{F}=65.654$, $\mathrm{p}$-value <0.001) and explains $15.6 \%$ of total variability. As the most decisive predictor for decisions on economic factor the employment in the mining company was identified (Table 4). Concerning the employees of the mining company, they rather agree with economic factor. On the other hand, the higher education of respondents was detected, the higher level of the disagreement with economic factor was measured. The correlation was also identified between the level of the income and the agreement with the economic factor. It can be concluded that the employees of the mining company, less educated population and population with higher income all agree with the economic development of the city based on mining.

These results can be commented in context of lack of education concerning environmental effects of 
coal mining, by long-term strong dependence of local economy on mining and lack of other entrepreneurial activities. The tradition of coal mining activities, which span over generations of local population, seems to be crucial driving force for support of coal mining despite of connected environmental pollution. Very low educational structure of local population creates assumptions for acceptance of mining as driving economic branch and supports image of mining as good paid job. This perception of employment in mining was widely supported during the socialistic era, when miners were presented as working class heroes and mining as heart of centrally planned economy. It is rather difficult to discuss support of coal mining by population with higher income. An explanation could be higher income of miners and lack of other local economic activities, where good wage could be earned.

The results of the regression model for environmental factor are more weaker, because it was possible to explain just $\mathbf{2 . 4} \%$ in variability of answers by measured segmentation criteria. In spite of this fact the results of the model are significant and thus statistically important $(\mathrm{F}=13.381, \mathrm{p}$-value $<-0.001)$. As the most important predictors former and contemporary employment at the mining company and age of respondents were identified.

As for employees of the mining company, they usually didn't agree with the statements of environmental factor. It was also determined that the older respondents were, the higher disagreement with statements of environmental factor appeared (Table 5). Thus it can be concluded that population which have never worked at the mining company, and younger respondents too, are persuaded about the importance of regeneration of post-mining sites for greenery and leisure time activities for the next development of their declining cities. This can be explained by generally stronger awareness of younger generation about environmental issues and by plenty of former miners between elderly population, whose productive age was closely linked to mining and times, when environmental aspects of quality of life were underestimated. As the next step the testing of influence of both extracted factors to level of agreement with expansion of coal mining was employed by means of the classic multiple linear regression with forward selection.

Table 4. Model of economic factor predictors. Results of a multiple linear regression as described in table 6

\begin{tabular}{|lcccc|}
\hline & $\mathrm{b}$ & $\begin{array}{c}\text { S. E. of } \\
\mathrm{b}\end{array}$ & $\mathrm{t}$ & $\mathrm{P}$ \\
\hline Intercept & 2.950 & 0.084 & 35.211 & -0.001 \\
\hline Education & 0.122 & 0.031 & 3.984 & -0.001 \\
\hline Income & -0.082 & 0.021 & -3.994 & -0.001 \\
\hline $\begin{array}{l}\text { Employment in } \\
\text { mining company }\end{array}$ & 0.346 & 0.033 & 10.610 & -0.001 \\
\hline
\end{tabular}

Source: own research and processing $(\mathrm{n}=1000)$
Table 5. Results of the multiple linear regression

\begin{tabular}{|c|c|c|c|c|}
\hline \multicolumn{5}{|c|}{ Model of environmental factor predictors } \\
\hline & $\mathrm{b}$ & S.E. of $b$ & $\mathrm{t}$ & $\mathrm{p}$ \\
\hline Intercept & 2.605 & 0.055 & 47.471 & $<-0.001$ \\
\hline Age & 0.045 & 0.015 & 3.098 & $<-0.01$ \\
\hline $\begin{array}{l}\text { Employment in } \\
\text { mining company }\end{array}$ & -0.114 & 0.029 & -3.904 & $<-0.001$ \\
\hline \multicolumn{5}{|c|}{$\begin{array}{c}\text { Model of agreement with predictors of the } \\
\text { expansion of coal mining }\end{array}$} \\
\hline Intercept & 0.291 & 0.128 & 2.271 & $<-0.05$ \\
\hline F1 & 1.025 & 0.037 & 27.449 & $<-0.001$ \\
\hline
\end{tabular}

Source: own research and processing $(\mathrm{n}=1000)$

The model that was cleaned of outliers shows the excellent level of prediction since it explains $43 \%$ of variability in answers on the mining expansion (Table 5). Just economic factor was identified as significant element. The level of agreement with expansion of mining in declining areas is thus influenced by the economic components of attitudes of respondents. This is related to the idea that coal mining is the basis for economic prosperity of this type of regions. As discussed above, these attitudes are deeply rooted in studied region especially between elderly people and former miners.

\section{Conclusion}

The depression areas are in difficult situation regarding their economic, social and environmental perspectives. This situation is complicated and difficult to solve as evidenced by the socio-economic development of the Karviná area in the last two decades, where the case study area of the presented research is located. One of the potential solutions of this situation is the suggestions to expand (or renew) the coal mining activities. With the respect to the fact that this proposed solution is rather controversial and does not propose sustainable plan for these areas in the long term horizon, the researches focused on the perception of expansion of mining by local population are quite actual and challenging. The presented research proved multidimensional way of an assessment of development tools applied in the depression areas.

The examined statements of respondents were divided into the economic and environmental factor. As the most important predictor in case of economic factor former or contemporary employment in mining company was identified. The higher education level of respondents was achieved, the more disagreement with the economic factor appeared. The correlation was also found between the level of income and the agreement with economic factor. It can be concluded that employees of the mining company, less educated population and population with higher 
income agreed with the economic development of the cities based on development of local coal mining. In case of environmental factor the employment at the mining company was also detected as the most decisive predictor.

The age of respondents can also be assigned to the group of important predictors. If the employees of the mining company are taken into account, they usually disagree with statements within the environmental factor. With the aging of respondents continuous growing disagreement with environmental factor statements was detected. It can be concluded that people that were never employed at the mining company and younger respondents are persuaded about undisputed relevance of regeneration of post-mining sites for greenery and leisure time activities for future development of this types of cities.

It is the common ground that the attitudes of different groups of population towards the expansion of mining strongly vary. This fact has to be necessarily taken into account when planning and developing the strategy of given cities, which raises intensive controversies. The finding of consensus on the expansion of coal mining in given areas will be highly complicated and has to be based on the evaluation of possible long-term benefits and consequent disadvantages from the economic, social and environmental points of view.

\section{Acknowledgments}

The paper was supported by the research project New methods for the more effective regeneration of brownfields to enable optimizing of the decision making processes (TDo20259) that is funded by the Technology Agency of the Czech Republic.

\section{References}

Alexandrescu, F, Martinát, S, Klusáček, P, Bartke, S 2014 , 'The Path From Passivity Toward Entrepreneurship: Public Sector Actors in Brownfield Regeneration Processes in Central and Eastern Europe', Organization $\mathcal{E}$ Environment.

Adelaja, S, Shaw, J, Beyea, W \& McKeown, J D Ch 2010, 'Renewable energy potential on brownfield sites: A case study of Michigan', Energy Policy, vol. 38, pp. 7021-7030.

Alker, S, Joy, V, Roberts, P \& Smith, N 200o, 'The definition of brownfield', Journal of Environmental Planning and Management, vol. 43, no. 1, pp. 49-69.

Bartsch, C \& Collaton, E 1997, Brownfields: Cleaning and reusing contaminated properties, Westport, CT, Praeger.

Buček, J, Bleha, B 2013, 'Urban shrinkage as a challenge to local development planning in Slovakia', Moravian Geographical Reports, vol. 21, no. 1, pp. 2-15.

Bontje, M 2004, 'Facing the challenge of shrinking cities in East Germany: The case of Leipzig', Geojournal, vol. 61, no. 1, pp. 13-21.
Bungart, R, Bens, O \& Hüttl, RF 200o, 'Production of bioenergy in post-mining landscapes in Lusatia: Perspectives and challenges for alternative landuse systems', Ecological Engineering, vol. 16, no. 1, pp. 5-16.

Cabernet 2006, Sustainable Brownfield Regeneration: Cabernet Network Report, University of Notthingham, 138 p.

CzechInvest 2008, National Strategy for Regeneration of Brownfields, Ministry of industry and business, Praha, 12 p.

Dvořáček, J 1998, 'K problematice útlumu uhelných dolů v Ostravsko-karvinském revíru', Acta Montanistica Slovaca, vol. 3, no. 1, pp. 85-88.

Fieldhouse, E \& Hollywood, E 1999, 'Life After Mining: Hidden Unemployment and Changing Patterns of Economic Activity amongst Miners in England and Wales, 1981-1991', Work, Employment and Society, vol. 13, no. 3, pp. 483-502.

Frantál, B 2008, 'Větrné elektrárny a NIMBY syndrom: analýza faktorů ovlivňujících vnímání a postoje obyvatel $\mathrm{k}$ rozvoji využití větrné energie', Udržitelná energie a Krajina, Veronica, Hostětín, pp. 21-26.

Frantál, B \& Kučera, P 2009, 'Impacts of the operation of wind turbines as perceived by residents in concerned areas', Moravian Geographical Reports, vol. 17, no. 2, pp. 3545.

Frantál, B \& Kunc, J 2010, 'Factors of the uneven regional development of wind energy projects (a case of the Czech Republic)', Geografický Časopis / Geographical Journal, vol. 62, no. 3, pp. 183-201.

Frantál, B \& Kunc, B 2011, 'Wind turbines in tourist landscape: Czech experience', Annals of Tourism Research, vol. 38, no. 2, pp. 499-519.

Frantál, B, Kunc, J, Nováková, E, Klusáček, P, Martinát, S \& Osman, R 2013, 'Location matters! Exploring brownfields regeneration in a spatial context (case study of the South Moravian Region, Czech Republic)', Moravian Geographical Reports, vol. 21, no. 2, pp. 5-19.

Frantál, B \& Nováková, E 2014, 'A curse of coal? Exploring unintended regional consequences of coal energy in the Czech Republic', Moravian Geographical Reports, vol. 22, no. 2 (in press).

Harfst, J \& Wirth, P 2011, 'Structural change in former mining regions: problems, potentials and capacities in multilevel-governance systems', Procedia - Social and Behavioral Sciences, vol. 14, pp. 167-176.

Haase, A, Bernt, M, Grossmann, K, Mykhnenko, V \& Rink, D 2013, 'Varieties of shrinkage in European cities', European Urban and Regional Studies, (in press).

Helios Rybicka, E 1996, 'Impact of mining and metallurgical industries on the environment in Poland', Applied Geochemistry, vol. 11, no. 1-2, pp. 3-9.

Ivanova, G, Rolfe, J, Lockie, S \& Timmer, V 2007, 'Assessing social and economic impacts associated with changes in the coal mining industry in the Bowen Basin, Queensland, Australia', Management of Environmental Quality: An International Journal, vol. 18, no. 2, pp. 211-228.

Káčerová, M, Ondačková, J, Mládek, J 2013, 'Contribution of population processes to population ageing: a comparison 
of the Czech and Slovak Republics', Acta Universitatis Palackianae Olomucensis, Facultas Rerum Naturalium, Geographica, vol. 44, pp. 27-43.

Klusáček, P, Kunc, J \& Nováková, E 2011, 'Potential of the brownfields sites for renewable energy development case study of the South Moravian Region (Czech Republic)' in B Frantál(ed.), Exploring New Landscapes of Energies. Proceedings of the Extended Abstracts from the Conference, CONGEO, Brno, pp. 38-39.

Krejčí, T Martinát, S \& Klusáček, P 2011, 'Spatial differentiation of the processes connected to the second demographic transition in post-socialistic cities (exampled on case of Brno and Ostrava - Czech Republic)', Moravian Geographical Reports, vol. 19, no. 2, pp. 10-21.

Krzysztofik, R Kantor-Pietraga, I \& Spórna, T 2013, 'A Dynamic View on the Typology of Functional Derelict Areas. A Research Proposal', Moravian Geographical Reports, vol. 20, no. 2, pp. 20-35.

Krzysztofik, R, Runge, J \& Kantor-Pietraga, I 2012, 'Paths of Environmental and Economic Reclamation: the Case of Post-Mining Brownfields', Polish Journal of Environmental Studies, vol. 21, no. 1, pp. 219-223.

Kunc, J, Martinát, S, Tonev, P \& Frantál, B 2014a, 'Destiny of Urban Brownfields: Spatial Patterns and Perceived Consequences of Post-Socialistic Deindustrialization', Transylvanian Review of Administrative Sciences, issue 41, no. E, pp. 109-128.

Kunc, J, Navrátil, J, Tonev, P, Frantál, B, Klusáček, P, Martinát, S, Havlíček, M \& Černík, J 2014b, 'Perception of urban renewal: reflexions and coherences of socio-spatial patterns (Brno, Czech Republic)', Geographia Technica, vol. 9, no. 1, pp. 66-77.

Lacina, J \& Koutecký, T 2005, 'Biogeographical and Geobiocoenological Aspects of Deep Coal Mining and its Impacts on Nature and Landscape in the Ostrava Region', Moravian Geographical Reports, vol. 13, no. 2, pp. 34 - 48.

Lockie, S, Franettowich, M, Petkova-Timmer, V, Rolfe, J \& Ivanova, G 2009, 'Coal mining and the resource community cycle: A longitudinal assessment of the social impacts of the Coppabella coal mine', Environmental Impact Assessment Review, vol. 29, no. 5, pp. 330-339.

Marcussen, H S 1982, 'Changes in the international division of labour: theoretical implications', Acta Sociologica, vol. 25, Suplement, pp. 67-78.

Moffat, S \& Pless-Mulloli, T 2003, 'It wasn't the plague we expected. Parents' perceptions of the health and environmental impact of opencast coal mining', Social Science and Medicine, vol. 57, no. 3, pp. 437-451.

Parry, J 2003, 'The Changing Meaning of Work: Restructuring in the Former Coalmining Communities of the South Wales Valleys', Work, Employment and Society, vol. 17, no. 2, pp. 227-246.

Ray, J J 1980, 'Does Living Near a Coal Mine Change Your Attitude to the Environment?: A Case Study of the Hunter Valley', Australian E New Zealand J. Sociology, vol. 16, no. 3, pp. 110-111.

Schmidt, H \& Glaesser, G 1998, 'Multitemporal analysis of satellite data and their use in the monitoring of the envi- ronmental impacts of open cast lignite mining areas in Eastern Germany', International Journal of Remote Sensing, vol. 19, no. 12, pp. 2245-2260.

Schulz, F \& Wiegleb, G 200o, 'Development options of natural habitats in a post-mining landscape', Land Degradation \& Development, vol. 11, no. 2, pp. 99-110.

Sklenička, P \& Charvátová, P 2003, 'Stand continuity - a useful parameter for ecological networks in post-mining landscapes', Ecological Engineering, vol. 20, no. 4, pp. 287296.

Smolová, I, Szczyrba, Z \& Jurek, M 2007, 'Současné trendy ve vývoji těžby nerostných surovin v ČR', Geografická revue, vol. 3, no. 1, pp. 130-148.

Strangleman, T 2002, 'Networks, Place and Identities in Post-industrial Mining Communities', International Journal of Urban and Regional Research, vol. 25, no. 2, pp. 253267.

Sucháček, J \& Malinovský, J 2012, 'Transformation processes in Ostrava: Hectic quest for a new identity', European Journal of Economics, Finance and Administrative Sciences, vol. 47, pp. 101-110.

Suopajärvi, L 2013,'Social impact assessment in mining projects in Northern Finland: Comparing practice to theory', Environmental Impact Assessment Review, vol. 42, pp. 25-30.

Strzyszcz, Z 1996,'Recultivation and landscaping in areas after brown-coal mining in middle-east European countries', Water, Air and Soil Pollution, vol. 91, no. 1-2, pp. 145157.

Symms, P 1994, 'The funding of developments on derelict and contaminated sites', in R Ball \& AC Pratt(eds.), Industrial Property: political and economic development, London, Routledge, pp. 63-82.

Tang, YT \& Nathanail, CP 2012, 'Sticks and Stones: The Impact of the Definitions of Brownfield in Policies on Socio-Economic Sustainability', Sustainability, vol. 4, no. 5, pp. 840-862.

Tvrdoň, M, Tuleja, P, Verner, T 2012, 'Economic Performance and the Labour Market in the Context of the Economic Crisis: Experience from the Visegrad Four Countries', E \& M Ekonomie a management, vol. 15, no. 3, pp. 16-31.

Vaishar, A 2002, 'Population development in the Ostrava region: Some aspects and current trends', Moravian Geographical Reports, vol. 10, no. 2, pp. 28-36.

Vaishar, A 2006, 'Demographic prognoses for some seats in the Ostrava region', Moravian Geographical Reports, vol. 14, no. 2, pp. 16-26.

Vargas-Sánches, A, Plaza-Mejía, MA \& Porras-Bueno, N 2009, 'Understanding Residents' Attitudes toward the Development of Industrial Tourism in a Former Mining Community', Journal of Travel Research, vol. 47, no. 3, pp. 373-387.

Vojvodíková, B, Potužník, M \& Bürgermeisterová, R 2011, 'The database on brownfields in Ostrava (Czech Republic): Some approaches to categorisation', Moravian Geographical Reports, vol. 19, no. 4, pp. 50-6o. 